President Nixon in 1969, would "provide strong leverage towards negotiating a verifiable agreement banning chemical weapons." He added: "Considering the current world situation, particularly the absence of a verifiable ban . . . the United States must also deter chemical warfare by denying a significant military advantage to any possible initiator."

Opposition to the Administration's plans is expected to focus on two main lines of argument. The first is the technical discussion about whether an increased chemical capability would, in fact, act as a deterrent to the Soviet Union, or whether - given some of the inherent limitations of binary weapons - it would make more sense to modernize existing stockpiles by more conventional means.

The second argument focuses on the opposition which is already developing in Western Europe, where the chemical weapons would have to be stored if, as expected, their main use was to be in a European theatre of war. According to critics of the Administration from both the left and the right, this opposition could lead to a destabilizing of the Atlantic Alliance which would, in itself, be an additional threat to national security.

Last year, the Administration's plans to build the production facility were approved by the Senate only by two votes in contrast in the House of Representatives there was a strong majority in favour of the new facility. This year the critics hope that the combination of a stringent budget outlook and forthcoming congressional elections will give them the votes needed to defeat the proposal to resume production; but with both the Defense Department and the White House apparently determined to push the proposal through, those trying to head it off recognize that they face a tough uphill task.

David Dickson

\section{Deep-sea mining}

\section{Fairer shares}

Brussels

A recent European Commission policy paper is urging that, when the world's developed and developing countries meet again in March at the International Conference on the Law of the Sea, to renew their fight over the mineral spoils of the deep seabeds, the EEC's member states should vote together in favour of a better deal for the mining consortia.

Europe, the Commission points out, is almost totally dependent on outside supplies of the minerals in question. Nearly all of Europe's cobalt, copper, manganese and nickel requirements are mined in the developing world, mostly in countries marked by political instability and a poor investment record.

Added to this are the national interests of the six consortia at present in the queue for mining licences. France is represented by the Association d'Etude et de Recherche des Nodules Polymetalliques (AFERNOD), which includes CNEXO (National Centre for the Exploration of the Oceans), the Le Nickel company and the atomic energy commissariat. Britain is represented by the Kennecott Copper Corporation, which is controlled by British Petroleum. Italy's ENI and Belgium's Union Minière Belge have interests in Ocean Mining Associates. Three German companies are partners in Ocean Management Incorporated and Holland's Bos Kalis is a member of the Ocean Mineral Company.

Although they have obvious interests in common, the member states have largely acted independently of one another. However, both the European Commission and the European Parliament would like the conference to decide on a joint EEC policy on raw materials. For the forthcoming round of negotiations the Commission recommends that the Ten should concentrate on ensuring that the mining consortia are not burdened to the point of non-profitability by restrictions and levies.

Mining permission by the proposed authority should be given impartially and there should, the Commission considers, be a way of appealing against decisions. However, the Commission rejects the idea that the authority should be funded by taxes levied in the mining consortia, pointing out that the financial risks of investing an estimated $\$ 1,000$ or 1,500 million to mine a site of 3 million tonnes are well above those required to extract the same amount of metal in a developing country. To counterbalance this, the Commission wants the law to guarantee that production levels as well as access to the markets can be maintained for the duration of a licence.

The developing countries see the problem as ensuring that their own mineral resources are not cut out of the market by competition from seabed mining. In addition, they are pressing for a transfer of technology and joint ventures, and hence a share of mining profits. The Commission is doubtful about how this would work out in practice and wants developing countries to share more of the risks involved.

Sources at the Commission suggest that since the conference ended last March little has happened to alter the negotiating positions of the opposing camps of developed and developing countries which are likely to remain at loggerheads this coming March.

Jasper Becker

\section{Small growth fund}

The address of the Treasurer of the Association for Research into Restricted Growth was given incorrectly in Nature 11 February. The following is the correct address: Pam Worsfold, 8 Cotswold Avenue, Rayleigh, Essex.
German academics

\section{Tenure vanishes}

\section{Hannover}

Since its inception 10 years ago, the policy of Berufsverbot, the exclusion of "political activists" from employment in West Germany's civil service, has meant not so much the dismissal of persons considered "extremist" but rather the blocking of their entry into public employment. In academic circles, therefore, the principal victims were young graduates who had formerly been members of (quite legal) left-wing student societies, and found themselves barred from an academic career.

But the recent "Campaign against Berufsverbot" conference in Hannover met under the shadow of a new threat, which has arisen as a result of the case of post office official Hans Peter, sacked for his political views after 30 years of service. After a vociferous campaign Peter's appeal was finally dismissed by the federal court last October.

The significance of the Peter case is that this is the first time a tenured official (Beamte) has been dismissed for his political views. West German employment policy recognizes three categories of employed person: "worker", "employee", and "Beamte". In return for job tenure for life, Beamte employees are expected to swear an oath to uphold the constitution. Anti-Berufsverbot campaigners explain that those barred from state employment for being activists are fully prepared to uphold the constitution (which guarantees freedom of conscience and opinion). What they are not always willing to do is to equate their loyalty to the constitution with unqualified support of specific government policies.

During the past 10 years, the spectrum of victims of Berufsverbot (the campaign lists some 5,000 cases of exclusion throughout the Federal Republic) has gradually widened from communists to socialists, to liberals, to the peace movement and most recently - to the ecology lobby.

The immediate threat of Berufsverbot policy to academics is indirect. Although the Peter case threatens any tenured position, during the past few years a tacit agreement has grown up in the universities that a scholar at risk would formally hold a non-tenured post, but would in other respects be treated as if fully tenured. However, recent cut-backs in university funding in West Germany have meant the abolition of a large number of non-tenured posts. Academics who have been at risk of Berufsverbot are thus being eliminated from the universities without the direct intervention of political considerations. With the scope of the screening process apparently becoming ever wider, and unemployment figures soaring, their prospect of finding other jobs seems bleak.

Vera Rich 